Bioscientia Medicina: Journal of Biomedicine $\&$ Translational Research

Journal Homepage: www.bioscmed.com

\title{
Are Parent Education Level Have Influence to Choose First Facility/Helper for Fracture in Children with Osteogenesis Imperfecta?
}

\author{
Yoyos Dias Ismiartoํㅐ, Doddy Putra Pratama Sudjana ${ }^{1}$, Mahyudin ${ }^{1}$, Sultan Agung Lumban Tobing ${ }^{1}$, \\ Anggrian $^{1}$, Wemdi Priya Prasetya ${ }^{1}$, Adriel Benedict ${ }^{1}$
}

${ }^{1}$ Department of Orthopaedic and Traumatology, RS Hasan Sadikin, Universitas Padjajaran, Bandung, Indonesia

\author{
A R T I C L E I N F O \\ Keywords: \\ Osteogenesis imperfecta \\ Education \\ Fracture
}

\begin{abstract}
Corresponding author:
E-mail address: yoyosismiartounpad@gmail.com (Yoyos Dias Ismiarto) All authors have reviewed and approved the final version of the manuscript.
\end{abstract}

https://doi.org/10.32539/bsm.v4i4.169

\begin{abstract}
A B S T R A C T
Introduction. Osteogenesis Imperfecta (OI) disease can develop fractures with or without trauma. Initial management of fracture cases depends on the patients' parents and it may affect the results. Various kinds of factors can influence parents' decision making in health issues, one of which is the level of education.

Methods.This research was conducted by analyzing the results of the questionnaire for the parental education level. Patients that fulfilled the inclusion criteria were part of the study from January to March 2020.

Results. The data showed that 38 (31\%), 31 (26\%), 29 (24\%), and $23(19 \%)$ patients were treated by bonesetters, hospitals, primary health care centers, and private clinics. There were $38(31 \%)$ parents who took their children to bonesetters, mostly have intermediate education level. Mostly parents with high level of education bring their children treated in hospitals $(49 \%)$. There was a significant correlation between their education level $(\mathrm{P}=0.000)$ regarding decision making in the first fracture case. Conclusion. The parents' educational level of patients diagnosed with OI affects decision making in determining the first treatment facility for managing cases of fracture.
\end{abstract}

\section{Introduction}

Osteogenesis Imperfecta (OI) is a group of disorders of bone formation that cause it to break abnormally. It threatens bone growth in children, and the characteristic that is often observed is that they can develop fractures with or without trauma. Furthermore, patients' bone growth may be inhibited since their body is sometimes shorter than normal size. ${ }^{1-3}$

The problems arising from patients are bone deformities, pain that causes impaired physical mobility, and failure to complete daily tasks. The obtained result showed 14 patients with Osteogenesis Imperfecta experienced lower muscle function and impaired physical mobility compared to their healthy counterparts. Physical mobility is a condition where the individual does not lose their overall ability to move but has decreased or limited activity. ${ }^{3-5}$

This disease (OI) is rare, occurring at rates between 1 / 10,000 and 1 / 25,000 on a global scale (Alharbi, 2016). In America, it is estimated that Osteogenesis Imperfecta patients range from 20,000 to 50,000 (Hasanah, 2013). According to (B.Pulungan, 2013), it is an inherited disease that occurs in one out of 20,000 children, in Indonesia. Therefore, with 80 million children, around 3000 suffer from Osteogenesis Imperfecta (OI). 5-7

Parental education level plays an important 
role in making appropriate decisions regarding medical treatment. The first treatment is very important in the handling of fracture cases, not only as management but as a diagnostic tool for patients. Therefore, this research is interested in examining the correlation between the level of parental education and the first treatment facility for fractures. $8-10$

Research on the correlation between parental education level and decision making in handling fracture cases in patients with Osteogenesis imperfecta, while good results depend on first handling of the case, therefore the authors are interested in examining the relationship between the level of parental education and first treatment facilities for fracture in children with osteogenesis imperfecta.

\section{Methods}

This study uses a retrospective analytic research design. This is a method primarily conducted to explain the research problem by looking back in time with a cross-sectional approach. This study analyzes the relationship between research variables. In a cross-sectional study, the research observes the measurement of variables at one time since it does not require follow-up. Furthermore, it analyzes the correlation between the level of parental education and the first treatment facility for fracture. The secondary data source was used by investigating the questionnaire provided in the period of 1 January -31 March 2020. The data obtained will be analyzed using SPSS and presented in tabular and graphical form.

\section{Results}

In this study, there were a total of 121 parents of patients consisting of $5,59,57$ with low (4\%), intermediate (49\%), and high education (47\%) respectively. Their work is classified into two groups, and the distribution of education and occupational levels can be seen in Figure 1. The correlation between the level of parental education and the first treatment facility for fracture in children with Osteogenesis Imperfecta is also shown.

Figure 2 shows the type of health facilities visited based on parental education level. Treatment such as traditional bone setters was the most visited facility with as many as 38 patients (31\%), followed by hospitals having up to 31 (26\%), primary health care centers 29 (24\%), and private clinics having up to $23(19 \%)$.

Considering the above results, it can be concluded that there is a correlation between the level of parental education and the first treatment facility for fracture in children with osteogenesis imperfecta $(\mathrm{P}=0,000)$. 


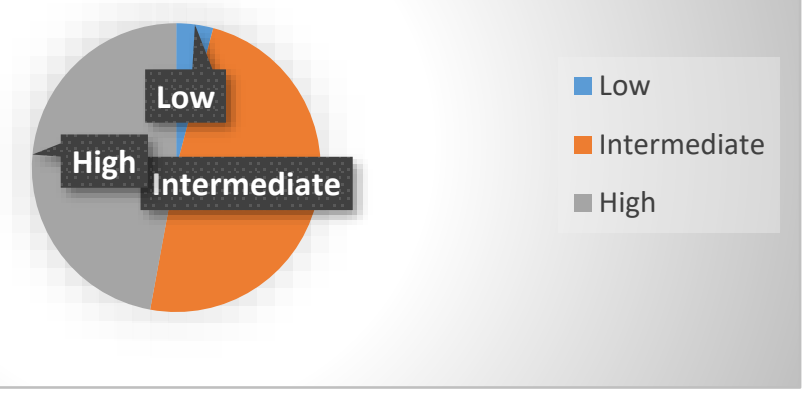

Figure 1. Level of Parental Education. The chart shows the level of parental education, where the proportion of subjects with intermediate education level were similar to the subjects with high education level (49\% and $47 \%)$. Only $4 \%$ of the subjects has low education level.

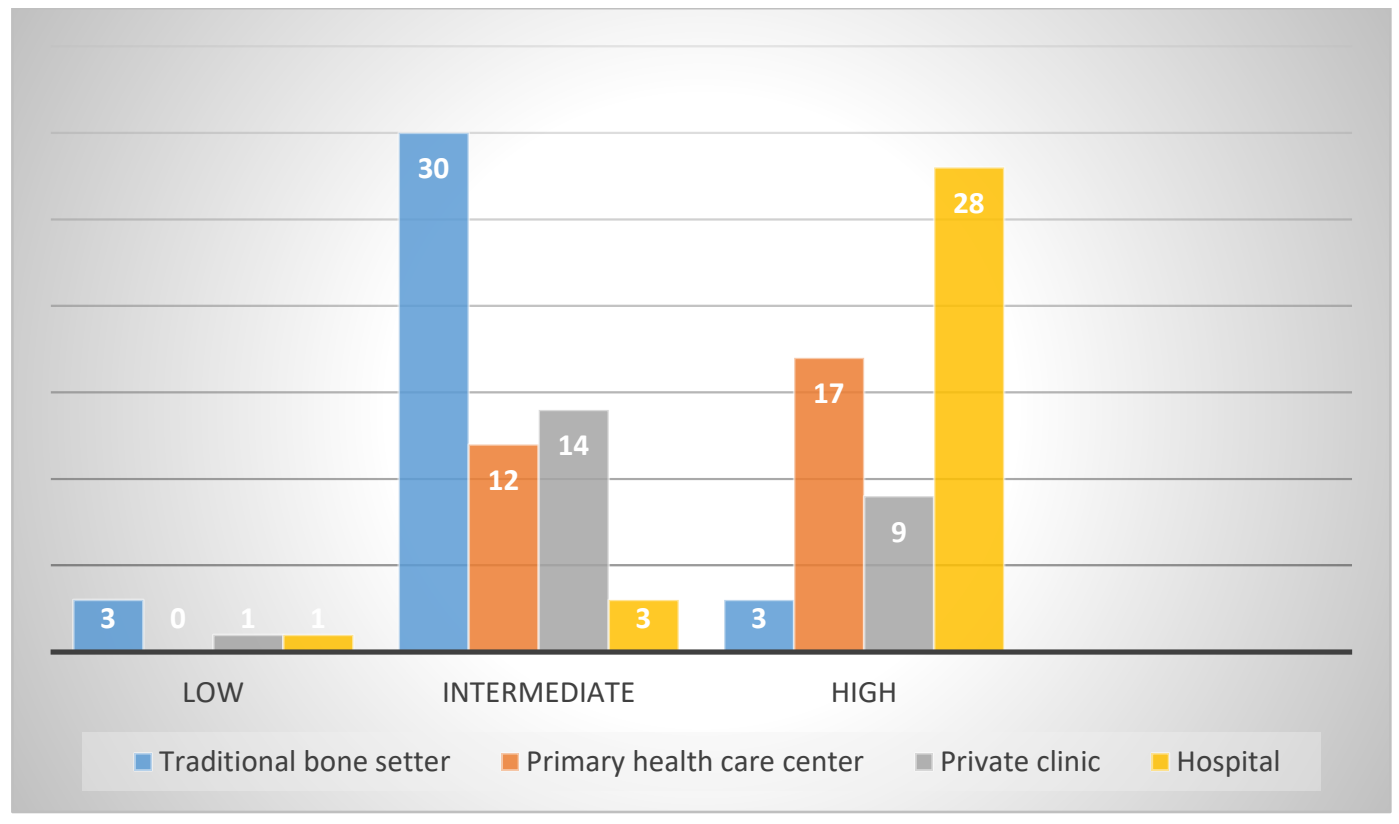

Figure 2. Type of health facilities visited based on parental education level. Most subjects with low and intermediate level of parental education visited traditional bone setters for initial treatment of OI. Subjects with high parental education level visited hospital and primary healthcare center for the initial treatment of OI.

\section{Discussions}

This research analyzes a total of 121 parents of patients with fracture cases in children diagnosed with osteogenesis imperfecta at RSUP Dr. Hasan Sadikin, during the period of 1 January 2010 - 31 March 2020. It examines the level of parental education that may affect decision making in the first management of fracture cases, and a significant correlation was obtained between these two variables $(\mathrm{P}=0,000)$.

The education level is a long-term process that uses systematic and organized procedures, in which managerial workforce learn conceptual and theoretical knowledge for general purposes. In another opinion, 
Azyumardi Azra reported that the education level of parents includes their activity in developing abilities, attitudes, and forms of behavior, both for the present and at the same time preparing for the future, even though it is through certain organizations or not.9-13

The advantage is that no research has directly investigated the correlation between parents' educational level of patients diagnosed with Osteogenesis Imperfecta and the selection of the first treatment facility since it is used as consideration for others. However, this can also be a lack of research, because it is difficult to compare with similar ones in other countries. ${ }^{5-9}$

\section{Conclusion}

The parents' educational level of patients diagnosed with OI affects decision making in determining the first treatment facility for managing cases of fracture.

\section{References}

1. Beary JF, Chines AA. Osteogenesis imperfecta. UpToDate. 2020.

2. Alharbi S. A Systematic Overview of Osteogenesis Imperfecta. Molecular biology. 2015;05.

3. Herring JA, Tachdjian MO, Texas Scottish Rite Hospital for C. Tachdjian's pediatric orthopaedics. Philadelphia: Saunders /Elsevier; 2008.

4. Arimbawa IM, Himawan IW, Rini ABPEA, Marzuki NS, Batubara JR. Panduan Praktik Klinis Ikatan Dokter Anak Indonesia : Osteogenesis Imperfekta. 1st ed: Badan Penerbit Ikatan Dokter Anak Indonesia; 2017.

5. Palomo T, Andrade MC, Peters BSE, Reis FA, Carvalhaes JTA, Glorieux FH, et al. Evaluation of a Modified Pamidronate Protocol for the Treatment of Osteogenesis Imperfecta. Calcified Tissue International. 2016;98(1):428.
6. Ihsan, Fuad. Dasar-Dasar Kependidikan. Jakarta:Rineka Cipta. 2011

7. Arikunto, S., Dasar-dasar Evaluasi Pendidikan, Jakarta : PT Rineka Cipta hal.210. 2009

8. Sudjiono, A. Pengantar Evaluasi Pendidikan, Jakarta: PT Raja Grafindo Persada. hal 63-64. 2011

9. Laksono, S. P., Qomariyah, \& Purwaningsih, E. (2011). Persentase Distribusi Penyakit Genetik dan Penyakit Yang Dapat Disebabkan Oleh Faktor Genetik, 13(2), 267-271.

10. Mariska, \& Auekari, E. Aspek Klinik, Genetik dan Molekuler Osteogenesis Imperfekta, 14(2), 95-110. 2007.

11. Xian CJ, Foster B. The biologic aspects of children's fractures. In Rockwood and Wilkins' Fractures in Children, 7th Ed. Beaty JH, Kasser JR (Eds). Lippincott Williams \& Wilkins, Philadelphia 2010.18-44

12. Goldman AB, Davidson D, Pavlov $\mathrm{H}$ et-al. "Popcorn" calcifications: a prognostic sign in osteogenesis imperfecta. Radiology. 1980;136 (2): 351-8

13. Rauch F, Glorieux FH. Osteogenesis imperfecta. Lancet. 2004;363 (9418): 1377-85 